\title{
The Dancer and the Body by Alfred Döblin
}

She was destined to become a dancer at the age of eleven. With her propensity for twisting her limbs and pulling faces and with her singular temperament, she seemed admirably suited for this profession. Until then her every step had been awkward; now she learned how to train her elastic ligaments and her double joints; she insinuated herself, cautiously and patiently, further and further, into her toes, her ankles, her knees, greedily ambushed the slender shoulders and bend of her thin arms, lurked over the play of her disciplined body. She managed to waft a chill over the most voluptuous dance.

At 18 her figure was a bare trace, as light as silk, her eyes dark and oversized. Her face was sharp in profile and long, like a boy's. Unseductive and unmusical, her voice was a shrill staccato; and she walked briskly and impatiently. She lacked affection, threw an unpitying gaze on her untalented colleagues and bored herself stiff with their complaints.

A wasting disease affected her at nineteen. Her face fringed by her black velvet chignon took on a China-doll look. Her limbs became heavy, but she continued to dance. When she was alone, she stamped her foot on the ground, threatened her body and struggled with it. She spoke to nobody about her weakness. She gritted her teeth in the face of this stupid, childish thing she had just learned to overcome.

When Ella bit her lips in pain, her mother threw herself on the sofa and wept for hours. After a week, the old woman made up her mind and told her daughter, while looking at the floor, that she had to put a stop to this and go to hospital. Ella made no reply, and simply shot a hateful look at the wrinkled, hopeless face.

The next day she went to the hospital. In the carriage she wept beneath her blanket for rage. She could have spat at her body, so bitter was her scorn for its suffering; she was disgusted by the nauseating flesh to whose company she was condemned. Mildly anxious, she opened her eyes and touched the limbs that no longer belonged to her. She was powerless, she was utterly powerless. They clattered over the cobblestones of the courtyard. The hospital gates closed behind her. She was aghast to see doctors and patients. The sisters lifted her gently into the bed.

Then the dancer lost her tongue. She could no longer hear her own voice's commanding tone. Everything happened without her will. They paid attention to every manifestation of her body, treated it with excessive seriousness. Daily, almost hourly, they asked the dancer how her body was faring and wrote it all carefully down in the dossier: at first she was indignant and then she became more and more astonished by it. Soon she entered a state of black fear and groundlessness; her body filled her with horror. She didn't dare touch it or even cleanse it; she stared at her arms and breasts, and shuddered when she inspected herself in the mirror. Her mouth swallowed the medicine that she gave it to drink. She followed the bitter drops as they trickled down her throat and wondered what her body made of them, this childish body, this dark master. She became as small as a fly; at night the fear of death stood behind her bed. Her eyes which had gazed into the uncanny became rigid. The sarcastic girl with the boyish face became pious and prayed at dusk with the sisters. Her mother was alarmed when she visited her daughter: her child had never been so dejected, so needy. 'We are all in God's hands,' said the mother to comfort the broken creature who clutched at her sleeve. 'Yes,' whispered the dancer, 'we are all in God's hands.'

The regular activity around her calmed her again, and her fright disappeared as quickly as it had come. Her aversion to the other patients in the ward flared up. And the indignation stood out on her sharp features that they should pay respect to this corrupt and corruptible thing while she was treated as if she were already dead. This was an affront to her imperious self. So she imprisoned her body, locked it in chains. Now it was her body, her property, over which only she had claim. She lived in this house; they ought to leave her house in peace. Every day they tapped her chest with hammers and eavesdropped on her heart's conversation. They even drew her heart on her chest, so that everybody could see it; and dragged into the light what had hidden within it. Yes, they robbed her of everything. With every question they took a bit of her away with them. They infiltrated her with poisons that were subtler than needles and probes; came at her with every trick in the book, drove her back into her bolthole. They robbed her of everything, the thieves, so it was no surprise to her that every day she felt weaker and just lay there, deathly pale. Then she became embittered and resisted. She lied to the doctors, refused to answer their questions, and even kept quiet about her pain. And when they came to ask her yet more questions, she went all rigid in bed, pushed the sisters away, and even laughed in a sudden blaze of hatred in the face of the doctors, who shook their heads. She shot them a sarcastic grimace.

But she couldn't maintain this frantic bravado for very long. Daily, without respite, the white coats went through the ward, percussing the patients, noting down everything. Daily, hourly, the sisters brought food and remedies: these made the dancer weaker. She resigned herself again to the game, and with a sour disdain let them do to her what they wanted. It was no business of hers what happened. A childish being lay there, and it was the source of her misery: why bother fighting on its behalf, what part of its dignity could she rightfully envy? She lay listless on her bed. The body was lying beneath her 
again, a piece of flesh; she paid no attention to its suffering. At night when it lanced and tormented her, she said to it: 'Be quiet until they do their rounds tomorrow; tell it to the doctors, your precious doctors, but leave me alone.' They ran separate households; the body could come to its own arrangements with the doctors. 'It will all be taken down in writing.' The burden of speaking was no longer hers.

Often she found herself smiling in commiseration with the stupid sick child lying in her bed. Calmly and conscientiously she recounted the source of its suffering. With indifference and a trace of mockery she observed the doctors, and noticed ironically that their efforts were having no effect. A tenseness, a hilarity came over her again, along with a fierce and uncontrollably malicious glee at the ineptitude of the doctors and the decomposition of the body. She pressed her mouth into the pillow to smother her bout of laughter: the old mockery and coldness had returned.

One day at noon, as soldiers paraded past the hospital to the melodious sound of marching music, the dancer sat up abruptly in her bed, eyes shining, lips pressed shut, completely bent over herself. After a while a sharp but discreet voice called the sister over to the bed. The dancer wanted to sew and needed silk and canvas. With a crayon she rapidly sketched a strange picture on the white cloth. There were three figures: a round misshapen body on two legs, without arms or head, nothing more than a fat ball with two legs. Beside him stood a large meek man with giant spectacles who caressed this body with a thermometer. But while he gave his full attention to looking after the body, on his other side a little girl jumped around barefoot, thumbing her nose at him with the left hand while stabbing a pair of sharp scissors from beneath into the body with the other hand, so that it leaked out in a thick stream like a punctured barrel.

The dancer embroidered the picture coarsely with red threads and laughed loudly to herself from time to time.

She wanted to dance again, to dance!

Like long before, she wanted to feel her will in action - when her taut body had moved like a flame and her mastery wafted a chill over the voluptuousness of her dancing. She wanted to dance a waltz, a marvellously suave waltz, with the one who had become her master: her body. With a movement of her will she could once more catch him by the hands - this body, this indolent animal, and throw him down, turn him around: he was no longer her master. A triumphant hate rose up within her; they weren't going to move, he to the right and she to the left, but both together - they were going to do a salto together. She wanted to roll this barrel, this limping manikin, along the floor, to spin him head over heels, to stuff his mouth with sand.

She called for the doctor in a voice all of a sudden become hoarser. Bent double, she looked up at his face, and saw the look of astonishment when he caught sight of her embroidery. Then she said to him quite calmly: 'You - you clown, you clown, you total wimp.' And throwing off the covers, she stabbed the sewing scissors into her left breast. A piercing shriek froze somewhere in a corner of the ward. Even in death, the dancer's mouth still bore a cold, contemptuous trait.

The Dancer and the Body, by Alfred Döblin translated from German by lain Bamforth, for the British Journal of General Practice.

DOI: 10.3399/bjgp09X473358

Die Tänzerin und der Leib by Alfred Döblin. Taken from: Erzählungen aus fünf Jahrzehnten. (C) Walter-Verlag AG, Plten, 1979. By permission of S. Fischer Verlag GmbH, Frankfurt am Main. 